\title{
ENGLISH ENVIRONMENT PROGRAMS AT POLYTECHNIC OF NATIONAL INFORMATICS
}

\author{
Fiviyanti Hasim ${ }^{1}$, Hamzah Machmoed ${ }^{2}$, Nasmilah $^{3}$ \\ ${ }^{1,2,3}$ Postgrade Student and Teaching staff of ELS, Faculty of Cultural Science \\ Hasanuddin University \\ fivi_faila@yahoo.com \\ hmzmachmoed@yahoo.com \\ imla63@yahoo.com.au
}

\begin{abstract}
English Environment Programs is one of method In Improving Speaking Ability At Polytechnic of National Informatics. This research aims at finding out wheather or not the use of English environment Programs improve the speaking ability. This research used Quasy experimental method with two group pre-test and post-test design. The result of the data analysis showed that the degree of freedom (df) was 43 $(\mathrm{n} 1+\mathrm{n} 2-2)$ where $\mathrm{n} 1=30$ and $\mathrm{n} 2=15$ so $30+15-2=43)$, the level of significant $(\alpha)=0.05$, the $\mathrm{t}$-test value of students' speaking ability $=3.765$, and the $\mathrm{t}$-table value $=2.021$. The $\mathrm{t}$-test value is greater than the t-table value $(3.765>2.021)$, this showed that there is a significant difference of improvement between the Control group and Experimental Group. It means that the Alternative Hypothesis $\left(\mathrm{H}_{1}\right)$ is accepted while the Null Hypothesis $\left(\mathrm{H}_{0}\right)$ rejected. Based on the result above, the researcher concluded that the using of English Environment Programs can improve the speaking ability of the second year students of Polytechnic of National Informatics

Keywords: English Environment, Speaking, Effectiveness
\end{abstract}

\section{Introduction}

English occupies a unique position among the language of the world. English is used more widely and by more people around the world then any other language as means of communication both internationally in every field:politics, economics and the social life.

As one of the developing countries, in order to be able to come into contact with the other countries of the world and to enter to the world arena to take a part in all sides of life; politically, socially, culturally, Indonesia needs English as a medium of international communication.

Besides the importance of English mentioned above, mastering English has also become more significant, for the improvement of human resources. Human resources is one of the factors that dominates in the over all development of Indonesia.
There many effort to raise the quality of life in Indonesia, for instance education in field which are in line with the demands of the globalization era. A key issue in education today is the need for providing capable human. Therefore, mastering English is very important in perparing for this era.

In relation to the statement above the Indonesian goverment has recognized the importance of English in this country, where the history of English as a foreign language in Indonesia began long time ago, that is during the dutch occupation of the country., verhaar (1984:26) in Jusmawati reveals that English has been though in Indonesia since independance in 1945, and was chosen by the goverment as a language of wider communication. Sice then, English has remained one of the foreign language which is most widely learned througout the country. 


\section{0 | JURNAL ILMU BUDAYA}

Volume 6, Nomor 1, Juni 2018

The Indonesian goverment has recognized that English has a special status in the republic by declaring it to be the first foreign language in the educational system. It is taught in junior and high school as one of compulsory subjects. The objectives of English teaching in these schools are as follows: (1) to develop the ability of the students to read effectively, (2) the ability to understand spoken English, (3) the ability to write, and (4) the ability to speak.

At the tertiary level, the students will use English for (1) reading refferences, since 90\% of the textbooks are written in English, (2) understanding lecturers of guest lecturers, (3) taking notes on lecturers by foreigners, (4) introducing Indonesia culture to other countries, and (5) communicating with foreigners, (ministrial decree, 1967).

When one consider the lenght of time spent in formal English learning, 6 years as secondary level and 2 to 4 years to tertiary level, it might be assumed that the learners' mastery og English is good. But there have been many complaints from the public that English language teaching and learning has not given satisfactory result. Secondary school students and most university and college students are not proficient in English. For example, Hamid in jusmawati (2004:16) in his research found that the majority of secondary students $(87,5 \%)$ have a proficiency level below $50 \%$ of the expected overall proficiency. They also can not express themselve in simple English sentences. Yusuf (1993:42), in this research found that average achievement of the science students of senior high school to comprehend reading material is fair. This situation challenge for us to deal with in order to improve the student' achievement in English as foreign language.

The unsatisfactory result of English teaching at the different levels, cannot be said to be affected by only one factor since there are many interacting factors which

\section{E-ISSN: 2621-5101 P-ISSN:2354-7294}

might be involved. In this relation, Baradja in Azadeh (2011) indentifies several factors hindering the English teaching process in secondary schools in Indonesia (1) teacher' professionalism, (2) number of learning hours, (3) condition learning resources center, (4) social support ( family and peer group), and (5) learners' motivation.

We cannot denied that the ability of the students in English relate with the teaching and learning process. In the classroom activity, it is not easy to make the students interested in the topic or materials given by the teacher and to make them participate or pay attention to class. Therefore, the teacher as a leader, manager and controller of his/her class, has a power to determine the way of study in the class. They have an important role to raise the students interest, by making more fun atmosphere and enjoyable classes that can stimulate the students to participate.

Improving the students' interest in class is the most important thing if the teacher wants to have a good result or successful in the teaching process. Psychological factors are related to the students' interests, motivation and attitudes. Furthermore, effective factors and other feelings can also occur in classroom or outside the classroom activities, such as lack of self-confidence, fear of being corrected, moral, etc. (Nur in Hamzah 2000).

Based on my observation in Polytechnic of National Informatis of Makassar, the students are very interested in Learning English through English Environment. The Activities include English Fun, No English No Service (English Day), English meeting Class, Vocabulary test and so many activities that the students do in their group or community. Therefore I am very interested to do the research about English Environment Program in learning English Specially for the second grade students at polytechnic of National Informatics.

\section{Review of Literature}




\section{1 | JURNAL ILMU BUDAYA}

Volume 6, Nomor 1, Juni 2018

There are some researcher have done some research related to English Environment. Azadeh Asgari (2011) in his study under the title "The Influence of Informal Language Learning Environment (Parents and Home Environment) On The Vocabulary Lerning Strategies which has purposed to investigate ESL students studying teaching English as a second language in University Putra Malaysia"[6]. This study adopted the qualitative method. The result of his reseach showed that the students' parents had different perceptions on the learning of the English language due to their education level. Besides, language teachers have an effect on the students' beliefs, behaviors, and their choice of VLSs. Other contributors are affecting the vocabulary learning strategies were classroom and peers. Second, Elizabeth Wilmer presented her research on the journal about The Influence of Learning Communities on The Interaction Levels of Development English Students [7]. The purposed of her research to determine if there was statistically significance difference in the level and type of interaction experience by learners based on course format and find the result is significance difference $\quad(\quad \mathrm{P}<.05)$ between students participating in a learning community in the level of peer interaction, the level of faculty interaction, but not on the perceived level of faculty concern, level of academic and intellectual development, and the level of institutional and goal commitment. The result of this research showed that all scales, the learning community students had a higher perceived level than the non learning communities student.

\section{Method}

This research applied a quasiexperimental design that involves two groups, experimental groups and control group. Population of this research are taken from the second grade students of

\section{E-ISSN: 2621-5101 P-ISSN:2354-7294}

Polytechnic of National Informatics. From population the researcher took sample by using cluster random sampling. For collecting research data, the researcher used interviewed and questionnaire. There are two groups sample namely Control group who implemented conventional class and Experimental group who are given treatment. All group were interviewed and the result of the data analysed by using quantitative method.

\section{Finding}

The data showed the rate percentage and frequency of the students' ability in speaking gained from pretest and post-test. There were variant score on the table of the students pretest at Control Group. The table [33] showed that from 30 students, none of them got very good and good scores. There were 1 student classified into Average score, 21 students were classified into poor score and 8 students were classified into very poor score. Whereas at table [34] showed that the rate percentage and frequency of the students ability in speaking gained from pretest at Experimental group.there were variant score on the table of the students pretest. The table showed that from 15 students, none of them got very good and good scores. There were 3 student classified into Average score, 7 students were classified into poor score and 5 student were classified into very poor score.

In post-test the table [40] showed that the rate percentage and frequency of the students' ability in speaking gained from post-test at control group. There were variant score on the table of the students pretest. The table showed that from 30 students, none students were classified into very good, 1 student got good score, 7 students got average scores. There were 15 students classified into poor score, 7 students classified into very poor score whereas table [41] showed that the rate percentage and frequency of the students' ability in speaking 


\section{2 | JURNAL ILMU BUDAYA}

Volume 6, Nomor 1, Juni 2018

gained from posttest at Experimental group. There were variant score on the table of the students' posttest. The table showed that from 15 students, there were not student classified into very good score. There were 1 student classified into good score, 5 students classified into average score, 6 students were classified into poor score and 3 students of them got very poor score

The improvement of students' speaking performance has interdependency correlation with the questionnaires. The finding verifies that there were same of the mean score between agree students and strongly agree students namely $35 \%$. There are $18 \%$ of neutral answer (undecided), $10 \%$ of disagree student, and there's only $1 \%$ responded disagree' statement.

\section{Discussion}

The description of the data collected through pre-test and post-test as explained in the previous section shows that the students' ability of the experimental treatment group improves significantly. It was supported by the mean score rate result of the students' pre-test and post-test of both control group and experimental group.

In students pre-test, the mean score of experimental group is higher than the control group $=58,6667>40,9667 .$. The researcher found that the t-observed value is higher than $\mathrm{t}$-table value, where $\mathrm{t}$-observed is 3.765 and $\mathrm{t}$ - table is 2.021 at 0.05 level of significant at 43 degrees of freedom (Tobserved < T-table, $\mathrm{o}=0.05)$. Sig. $(2$ tailed $)$ is 0,001 which is lower than 0,05 . Therefore, we can conclude that two groups had difference speaking competence.

In Control group's post-test, there is a significant improvement. The mean score in pre-test enhance from 33.9 to 40.97 in post test. The mean difference in paired sample test shows the number of 7.07 (40.97 33.9) with the standard deviation of it 9.99. The researcher found that the $\mathrm{t}$-observed

\section{E-ISSN: 2621-5101 P-ISSN:2354-7294}

value is higher than $\mathrm{t}$-table value, where $\mathrm{t}$ observed is 3.053 and $t$ - table is 2.045 at 0.05 level of significant at 29 degrees of freedom (T-observed > T-table, $\alpha=0.05$ ). Sig. (2 tailed) was same 0.05. The comparison data between pre-test and post test indicates that the mean score is significantly different. ln Experimental groups" post-test. there is also a larger improvement. The mean score in pre-test enhance from 35,20 to 58,67 in post test. The mean difference in paired sample test shows the number of 23.47 (58.67-35.20) with the standard deviation of it 9.627. The researcher found that the $\mathrm{t}$-observed value is higher than $\mathrm{t}$-table value, where $\mathrm{t}$-observed is 9.440 and $t$ table is 2.145 at 0.05 level of significant at 14 degrees of freedom (Tobserved > T-table $\alpha=0.05$ ). Sig.(2 tailed) is 0,000 which is lower than 0,05 .

The comparison data between pre-test and post test of experimental group indicates that mean score is significantly different. The comparison data post test of Experimental and Control indicates that eventhough both classes improved significantly, but Experimental class shows a higher significant improvement.

The outcome of the students' improvement of Experimental and Control display a significant difference. The researcher found that the tobserved value is higher than $\mathrm{t}$-table value, where $\mathrm{t}$-observed is 3.765 and $t$ - table is 2.021 at 0.05 level of significant at 43 degrees of freedom (tobserved > T-table, $\mathrm{c}=0.05)$. Sig. $(2$ tailed $)$ is 0,001 which is lower than 0,05 . Thus, the hypothesis stated that English Environment Program improves the students' speaking performance is approved ability. The comparison data of the tw0 groups" improvement indicates that null hypothesis (Ho) is rejected and the alternative hypothesis (H1) is accepted.

English Environment Program is categorized as skill orientation development. 


\section{3 | JURNAL ILMU BUDAYA}

Volume 6, Nomor 1, Juni 2018

In this context, it is quite suitable to develop communication skills particularly for students. The finding of this study indicates that most of the students have high interest in learning through English Environment Program. Through the questionaire and interview it was found that $73 \%$ of the students stated that they really got direct learning. On the other hand all students the respondents stated EEP make them speak in the classroom. This happen because they realize the meaningful experience through EEP they are very active and participate in the classroom. Some shy students stated that before they were very passive as all learning was only listening to what teachers were saying during the class.

It can not be denied that learning situation plays very significant role to make students enjoy learning. EEP makes learning English enjoyable. The finding from the questionaire showed that $73 \%$ of the students like the Englih Environment Programs because the process of learning English becomes more dynamic since there are variety of activities done and all students do variety of roles so there is no bored in learning English. Students stated they enjoy learning to speak English and guiding skills at the same time. Doff (1988:223) stated that what ever the teacher provided in the class but if the condition is unenjoyably the learning is not fruitful.

The researcher found that most of the students $(73 \%)$ stated that the strategies implemented in EEP eliminated psychological burdens. Morris (2006:34\} stated that positive psychological condition of teaming makes the learning more effective. The steps in learning help students reduces their anxiety such as practicing in small group or in pairs so till they get success in mastering the conversation then act in front of the people.. The finding shows that most of the students themselves stated that through activities done they are 'not

\section{E-ISSN: 2621-5101 P-ISSN:2354-7294}

afraid of speaking because body movement or acting can help them to smothen their communication. Generally students get nervous to speak English because the teacher suddenly just appoints them to carry out a conversation before leading them to master it first.

\section{Conclussion}

Based on the findings and disscussion of the research result, it can be concluded that

1. the used of English Environment Program significanly improve speaking ability of the second year students of Polytechnic of National Informatics . It is proved by $\mathrm{t}$ test value

2. English Environment Program Effect the students' motivation in learning English. It proved by the result of Questionnaires shown $73 \%$ of students at Experimental Group chose strongly agree and agree with the English Environment Program.

\section{BIBLIOGRAPHY}

Amirullah. 2009.Improving The Interest an Speaking Ability of the Students of SMP Negeri 1 Mare by Using VCD/DVD Films. Faculty of Language and literature. State University of Makassar.

Asgary,Azadeh. 2011. The Influence of Informal Language Learning Environment (Parents and Home Environment) on the vocabulary learning strategies. English Language and Literature studies. University Putra Malaysia. Serdang.

Brown, H.D. 1980. Principle of Language Learning Practice.

Hall Avlengilewood cifiil. USA.

Hamzah. 2002. Minimizing The Students Anxiety Of Sltpn 14 Makassar To Speak Through English Meeting, Makassar: Faculty of Language and literature. State University of Makassar. 
114 | JURNAL ILMU BUDAYA

Volume 6, Nomor 1, Juni 2018

Delukman. 2016. Konsepsi program English Coordinator 2016. Makassar.Polinas.

Harmer, J. 1991. The practice of English Language Teaching. Longman. London.

Jusmawati, 2004. Improving The Students Speaking Ability Through English Films. Faculty of Language and literature. State University of Makassar.

Miles, M. B. and Huberman, A. M. 1994. Qualitative Data Analysis: An Expanded Sourcebook. London: Sage.

Mouna, Travis. 2009. Home lingual environment effect on development of child's language in multilingual daycare. Thesis. Pirkanmaa University of Applied Sciences. Degree Programme in Social Services.

Nurjannah, 2000.Using Caridatures in Teaching Speaking to The Third Semester Students of English Deparment FBS UNM. Makassar: Faculty of Language and literature.Makassar. State University of Makassar

Ronny Setiawan dkk. 2000. Standart Operational Procedur LP3I. Jakarta. LP3I

Sugiyono, 2013. Statistika untuk Penelitian. Bandung. Alfabeta

Talib, Rasuna, 2000. The Impact of Private English Course on The English Achievement of Senior High School Students in Gorontalo Municipality.
E-ISSN: 2621-5101 P-ISSN:2354-7294

Thesis.English Language Studies. Graduate Program in Hasanuddin University

Ur, Penny, 1996. A Course in Language Teaching:Practice and Theory. Cambridge: Cambridge University Press.

Wandia, I. K. 1990. A Psychological Constrainst Affecting speaking performance in the fifth semester students of the English Deparment. Faculty of Letters Udayana. University Denpasar-Bali. Thesis. English language studies program.Hasanuddin University. Ujung Pandang.

Wilmer,Elizabeth. 2009. The Influenceof Learning Communities on The Interaction :Levels of Development English Students. The Journal of the Virginia Community Colleges.

Oxford, Rebecca L. 2003. Language Learning Style and Strategies: An Overview. Learning Styles and strategies/Oxford, GALA 2003.

Yusuf Muhammad. 1993. Reading comprehension of science students of SMU Negeri Ujung Pandang for Natural Science Reading Material. Thesis. Ujung Pandang.IKIP

Cluster random sampling, (www.sagepub.com/ upm-data/408035.pdf). . 2016. Buku Panduan Polinas.Jakarta. Lp3I. 